\title{
Pemetaan Sebaran Tingkat Alih Fungsi Lahan Sawah di Kabupaten Serang
}

\author{
Faujatul Hasanah ${ }^{1 *}$ \\ Iwan Setiawan' \\ Trisna Insan Noor ${ }^{3}$ \\ Eka Purna Yudha ${ }^{4}$ \\ ${ }^{1}$ Mahasiswa Pascasarjana Fakultas Pertanian, Universitas Padjadjaran \\ 2,3,4 Fakultas Pertanian, Universitas Padjadjaran \\ *email: faujatulhasanah@gmail.com \\ Diterima: Maret 2021; Disetujui: September 2021; Dipublish: Oktober 2021
}

\begin{abstract}
Abstrak
Lahan merupakan sumber daya alam yang mempunyai fungsi penting guna memenuhi berbagai kebutuhan manusia. Data statsitik tahun 2019 menunjukkan bahwa 71,34\% wilayah Kabupaten Serang merupakan lahan pertanian, Namun seiring pertumbuhan ekonomi dan jumlah penduduk, luas lahan pertanian terutama lahan sawah di Kabupaten Serang semakin berkurang akibat alih fungsi lahan menjadi non pertanian. Tujuan penelitian ini adalah melakukan pemetaan sebaran tingkat alih fungsi lahan sawah di Kabupaten Serang. Penelitian ini menggunakan desain kuantitatif dan metode studi literatur dengan alat analisis spasial yang diolah menggunakan software ArcGIS. Hasil penelitian adalah berupa peta sebaran tingkat alih fugsi lahan sawah di Kabupaten Serang. Luas lahan sawah di Kabupaten Serang mengalami penurunan sebesar 2,78\% dalam kurun waktu 2015-2019. Wilayah yang berbatasan langsung dengan kota-kota besar seperti Kota Cilegon, Kota Serang, dan Kabupaten Tangerang menunjukan adanya penurunan luas lahan sawah dalam kategori tinggi, diantaranya Kecamatan Tanara, Ciruas dan Mancak dengan penurunan luas lahan sawah berturut-turut sebesar 478,10 hektar; 340,70 hektar; dan 334,00 hektar. Diharapkan ketegasan pemerintah daerah perihal perizinan aktivitas pembangunan semua sektor, penetapan wilayah berdasarkan keunggulannya, serta perlu adanya peraturan yang jelas dan tegas mengatur tentang lahan pertanian yang dilindungi, terutama lahan sawah.
\end{abstract}

Kata Kunci: alih fungsi; arcGIS; lahan sawah; pemetaan

\begin{abstract}
Land is a natural resource that has an important function to meet various human needs. Statisticitic data in 2019 shows that 71.34\% of Serang Regency is agricultural land. But along with economic growth and population, the area of agricultural land, especially rice fields in Serang Regency, is decreasing due to the conversion of land to non-agriculture. The purpose of this study is to map the distribution of the conversion rate of rice fields in Serang Regency. The study uses quantitative design and literature study methods with spatial analysis tools processed using ArcGIS software. The results of the study are in the form of a map of the distribution of the conversion rate of rice fields in Serang Regency. The area of rice fields in Serang Regency decreased by 2.78\% in the period 2015-2019. Areas directly adjacent to major cities such as Cilegon City, Serang City, and Tangerang Regency showed a decrease in rice field area in the high category, including Tanara, Ciruas and Mancak districts with consecutive decreases in rice field area of 478.10 hectares; 340.70 hectares; and 334.00 hectares. It is expected that the firmness of the local government regarding the licensing of development
\end{abstract}


activities of all sectors, the determination of areas based on their advantages, and the need for clear and firm regulations governing protected agricultural land, especially rice fields.

\section{Keywords: conversion; ArcGIS; rice fields; mapping}

\section{PENDAHULUAN}

Lahan adalah lingkungan fisik yang terdiri dari beberapa komponen seperti tanah, iklim, relief, hidrologi dan vegetasi, yang dapat digunakan oleh makhluk hidup untuk keberlangsungan kehidupannya. Penggunaan lahan merupakan suatu proses interaksi manusia dengan alam atau proses dari aktfitas manusia dalam memanfaatkan potensi alam demi keberlangsungan hidupnya. (Muiz et al., 2009)

Alih fungsi lahan atau perubahan penggunaan lahan pada dasarnya merupakan peralihan fungsi lahan dengan tujuan tertentu. Perubahan lahan dapat terjadi karena berbagai faktor, seperti pemekaran atau perkembangan wilayah, adanya kebijakan pembangunan dari pemerintah, dan pertumbuhan penduduk. (Hauser et al., 1985)

Steinhäußer et al., (2015) menyatakan bahwa fenomena perubahan penggunaan lahan menjadi isu penting ketika kebutuhan akan penggunaan lahan tidak terpenuhi oleh ketersediaan lahan yang ada. Diantara beberapa penggunaan lahan pertanian yang ada di Indonesia, lahan sawah mempunyai tingkat kerentanan yang tinggi untuk teralihfungsi menjadi penggunaan lainnya (Widiatmaka et al., 2013)

Menurut Bringezu, et al., (2014), perubahan penggunaan lahan yang terjadi pada umumnya diakibatkan oleh tekanan penduduk karena aktivitas ekonominya yang dapat meningkatkan tekanan pada sumber daya lahan. Alih fungsi lahan sawah menjadi non pertanian terjadi hampir di setiap wilayah, tak terkecuali di Kabupaten Serang.

Kabupaten Serang memiliki luas wilayah sebesar 146.735 Ha. Data Statistik tahun 2019 menunjukkan lahan sawah di Kabupaten Serang yang tersedia hingga saat ini adalah $47.573 \mathrm{Ha}$ hamparan lahan sawah dan $55.368 \mathrm{Ha}$ lahan pertanian bukan sawah. Selain itu, Kabupaten Serang juga terdiri dari 43.794 Ha lahan bukan pertanian. Lahan sawah di Kabupaten Serang paling besar digunakan dengan saluran irigasi, yaitu sebesar 26.153,7 Ha (54,98\%) dan tadah hujan 21.419,3 Ha $(45,02 \%)$ dari luas lahan sawah. Sedangkan lahan pertanian bukan sawah sebagian besar digunakan untuk tegal/kebun (19.335,1 Ha), perkebunan (10.972 Ha), hutan rakyat (8.863 Ha), ladang (5.900,7 Ha), sementara tidak diusahakan (2.290,5 $\mathrm{Ha}$ ), padang rumput (5 $\mathrm{Ha}$ ), dan lainnya (8.001,7 Ha). (Badan Pusat Statistik Provinsi Banten, 2019)

BAPPEDA Kabupaten Serang (2018) menyatakan bahwa Kabupaten Serang merupakan daerah yang potensial dan diuntungkan secara geografis. Aksesibilitas keluar masuk wilayah Kabupaten Serang cukup strategis karena dilalui oleh Jalan Tol JakartaMerak yang merupakan akses utama dari dan menuju Pulau Sumatera melalui Pelabuhan Penyeberangan Merak, 
sehingga menjadikan Kabupaten Serang sebagai wilayah transit perhubungan darat antara Pulau Jawa dan Pulau Sumatera. Kabupaten Serang juga merupakan daerah alternatif dan penyangga (hinterland) Ibukota Negara dengan jarak sekitar $70 \mathrm{Km}$ jika diukur melalui jalan Tol Jakarta-Merak.

Banyak warga Kabupaten Serang menggantungkan hidupnya dari sektor pertanian, tercatat sebanyak 127.438 rumah tangga merupakan rumah tangga usaha pertanian (Badan Pusat Statistik Kabupaten Serang, 2013). BPS Provinsi Banten (2019) juga menyatakan bahwa penggunaan lahan pertanian di Kabupaten Serang adalah seluas 102.941 $\mathrm{Ha}$ atau $70,15 \%$ dari luas total wilayahnya. Persentase penggunaan lahan yang luas dapat dikatakan Kabupaten Serang merupakan daerah yang menonjol kegiatan pertaniannya. Kabupaten Serang merupakan daerah pertanian terbesar ketiga di Provinsi Banten setelah Kabupaten Pandeglang dan Kabupaten Lebak.

Pontensi-potensi yang dimiliki Kabupaten Serang menimbulkan interaksi dengan daerah-daerah sekitarnya yang kemudian memberikan pengaruh terhadap pertumbuhan suatu wilayah. Pertumbuhan ekonomi di suatu daerah menjadi penarik bagi masyarakat untuk bermigrasi ke daerah tersebut. Berkembangnya aktivitas ekonomi dan meningkatnya jumlah penduduk menyebabkan terjadinya peningkatan kebutuhan akan lahan. Kabupaten Serang juga berperan sebagai kawasan pemenuh kebutuhan akan lahan terutama untuk aktivitas pertanian, industri, transportasi dan tempat tinggal. Selain itu, dampak arus migrasi yang terjadi juga akan mempengaruhi perubahan aktivitas masyarakatnya yang kemudian dapat menimbulkan perubahan penggunaan lahan pada wilayah ini.

Hakim (2002) menyatakan bahwa pertumbuhan ekonomi yang tinggi menimbulkan pertumbuhan yang pesat dibeberapa sektor ekonomi. Menurut kajian yang dilakukan oleh Mustopa (2011), pertumbuhan ekonomi membutuhkan lahan yang lebih luas guna pembangunan diberbagai sektor terutama industri, hal tersebut menyebabkan peningkatan kebutuhan lahan. Pentingnya lahan bagi berbagai sektor 4 tersebut mengakibatkan permintaan akan penggunaan lahan semakin meningkat, hal ini sejalan dengan semakin meningkatnya pertambahan penduduk, namun keters\ediaan lahan relatif terbatas, karena lahan merupakan faktor produksi yang tidak dapat diproduksi oleh manusia (Mubyarto, 1996).

Jika lahan sawah sebagai sumber penghidupan penduduk semakin tergerus, maka akan semakin banyak penduduk yang akan kehilangan mata pencahariannya. Banyak petani yang enggan lagi untuk mau mengolah lahan sawah dikarenakan telah banyaknya lahan yang tidak lagi dimiliki oleh para petani. Akhirnya banyak petani yang memilih untuk menjadi buruh industri.

Masalah alih fungsi lahan semakin kompleks sejalan dengan pertumbuhan ekonomi suatu wilayah. Pemerintah daerah semakin intensif melakukan upaya untuk mendorong investor 
berinvestasi di daerahnya. Hal tersebut tentunya memiliki konsekuensi dalam mempercepat alih fungsi lahan sawah menjadi non-pertanian. Apabila alih fungsi lahan pertanian, khususnya sawah terus terjadi, maka akan menimbulkan berbagai persoalan, terutama dalam pencapaian ketahanan pangan di Kabupaten Serang.

Menurut Direktorat Pengelolaan Lahan (2006), salah satu upaya yang diperlukan guna mengatasi masalah pengelolaan sumberdaya lahan pertanian, terutama alih fungsi lahan pertanian, yaitu dengan melakukan identifikasi dan pemetaan penggunaan lahan secara periodic. Hal tersebut membantu inventarisasi penyebaran lahan pertanian, faktor penyebab, dampak yang ditimbulkan, dan usaha untuk mengembalikan penggunaan semula. Hasil evaluasi ini dapat dijadikan bahan pertimbangan dalam pneyusunan kebijakan penataan ruang dengan mengutamakan eksistensi lahan pertanian.

Masalah alih fungsi lahan sawah semakin kompleks sejalan dengan pertumbuhan ekonomi Kabupaten Serang. Pertumbuhan ekonomi memicu berkembangnya industri di Kabupaten Serang dan mengakibatkan terjadinya urbanisasi penduduk menuju Kabupaten Serang. Hal tersebut dapat berakibat semakin meningkatnya kebutuhan lahan dan terjadinya alih fungsi lahan guna memenuhi kebutuhan penduduk maupun aktivitas perekonomiannya.

Pemerintah daerah semakin intensif melakukan upaya untuk mendorong investor berinvestasi di daerahnya. Hal tersebut tentunya memiliki konsekuensi dalam mempercepat alih fungsi lahan sawah menjadi non-pertanian. Apabila alih fungsi lahan sawah terus terjadi, maka akan menimbulkan berbagai persoalan, terutama dalam pencapaian ketahanan pangan di Kabupaten Serang.

Oleh karena itu, perlu dilakukan penelitian guna membuat suatu sistem basis data dalam bentuk pemetaan laju alih fungsi lahan sawah. Diharapkan basis data alih fungsi lahan sawah mampu menjawab kebutuhan informasi dengan aspek kuantitas, kualitas, kecepatan, serta ketepatan waktu. Penelitian ini bertujuan untuk melakukan pemetaan lahan sawah teralihfungsi pada setiap kecamatan di Kabupaten Serang. Peta tersebut kemudian dapat digunakan pemerintah sebagai panduan guna mengetahui lokasi lahan sawah teralihfungsi serta yang masih tersedia dan perlu dipertahankan.

\section{METODE PENELITIAN}

Penelitian dilakukan di Kabupaten Serang menggunakan data publikasi dari Badan Pusat Statistik Kabupaten Serang tahun 2015-2019. Metode pengumpulan data dilakukan dengan menggunakan teknik survey data sekunder yang terdiri dari survey instansional untuk memperoleh data yang relevan dengan pembahasan penelitian, serta study literatur.

Pemetaan sebaran lahan sawah teralihfungsi dilakukan dengan memanfaatkan Sistem Informasi Geografis (SIG) dan diolah menggunakan software ArcGIS 10.2.2. Peta dikategorikan berdasarkan penurunan 
luas lahan sawah. Bahan yang digunan dalam penelitian ini antara lain: (1) Peta Kabupaten Serang berdasarkan kecamatan tahun 2019; (2) peta Rupa Bumi Indonesia Kabupaten Serang Skala 1:100.000; (3) data luas lahan sawah menurut kecamatan tahun 2015-2019.

Metode yang digunakan dalam penelitian ini terdiri dari tahapantahapan antara lain sebagai berikut:

a. Studi literatur, yaitu melakukan penelusuran informasi dari website situs resmi pemerintah dan bukubuku yang berhubungan dengan lahan pertanian khususnya lahan sawah, buku pengenalan ArcGIS, buku konsep dasar-dasar GIS, dan sebagainya guna memperoleh data.

b. Observasi lahan sawah di Kabupaten Serang, yaitu mengamati secara langsung lokasi sawah yang masih produktif pada setiap kecamatan di Kabupaten Serang

c. Pengumpulan data, yaitu mengumpulkan dan mengidentifikasi data yang diperoleh sesuai kebutuhan.

d. Proses analisis data, yaitu kegiatan identifikasi data spasial dan non spasial (jenis dan luas lahan sawah) pada setiap kecamatan.

e. Proses identifikasi layer, yaitu mengimplementasikan data yang sudah dianalisis ke dalam software ArcGIS 10.2.2 dengan mengidentifikasi layer dalam format data vector

f. Proses digitasi, yaitu proses implementasi sistem ke dalam ArcGIS dengan membuat peta digital

g. Peta digital, dimana hasil dari digitasi berupa peta digital

h. Geographic Information System alih fungsi lahan sawah di Kabupaten Serang, dimana hasil pemetaan menghasilkan informasi mengenai lahan sawah teralihfungsi di 29 kecamatan di Kabupaten Serang.

Pada proses analisis data, tingkat alih fungsi lahan dibangun dengan membangun kategorisasi pada setiap nilai penurunan luas lahan sawah. Tingkat alih fungsi lahan sawah berpedoman pada kategorisasi menurut Azwar (2000), dimana langkah pertama untuk membuat kategorisasi adalah dengan menetapkan kriterianya terlebih dahulu. Hal tersebut tidak terlepas dari berapa jumlah kategori yang akan kita buat, misalkan 3 kategori (rendah, sedang, tinggi). Guna mengkategorikan hasil pengukuran menjadi tiga kategori, pedoman yang bisa digunakan adalah:

$$
\begin{array}{ll}
\text { Rendah } & : \mathrm{X}<\mathrm{M}-1 \mathrm{SD} \\
\text { Sedang } & : \mathrm{M}-1 \mathrm{SD} \leq \mathrm{X}<\mathrm{M}+1 \mathrm{SD} \\
\text { Tinggi } & : \mathrm{M}+1 \mathrm{SD} \leq \mathrm{X} \\
\text { Dimana, } \mathrm{M}= & \text { Mean; } \mathrm{SD}=\text { Standar Deviasi. }
\end{array}
$$

\section{HASIL DAN PEMBAHASAN}

Kebutuhan lahan yang semakin meningkat, serta terbatasnya ketersediaan lahan, menyebabkan persaingan dalam pemanfaatan lahan dan pada akhirnya lahan yang ada diperuntukan bagi penggunaan yang memberikan manfaat ekonomi lebih besar. Sawah sebagai penghasil terbesar untuk produksi padi tidak dapat dihindari dari alihfungsi lahan, hal ini dikarenakan manfaat ekonomi untuk penggunaan sawah relatif lebih kecil dibandingkan manfaat ekonomi untuk penggunaan non pertanian. Selain itu sawah merupakan alternatif yang siap dari aspek topografis dan aksesbilitas 
JURNAL AGRICA Vol.14 No.2/Oktober 2021

Available online http://ojs.uma.ac.id/index.php/agrica 10.31289/agrica.v14i2.5039

untuk dialihfungsikan.

Irawan (2016) menyatakan bahwa alih fungsi lahan lebih besar terjadi pada lahan sawah dibandingkan dengan lahan kering, hal ini dikarenakan tiga faktor, yaitu (1) pembangunan kegiatan non pertanian seperti kompleks perumahan, pertokoan, perkantoran, dan kawasan indutri lebih mudah dilakukan pada lahan sawah yang lebih datar dibanding lahan kering; (2) akibat pembangunan masa lalu yang terfokus pada upaya peningkatan produksi padi, maka infrastruktur ekonomi lebih tersedia di daerah persawahan daripada daerah lahan kering; (3) daerah persawahan secara umum lebih mendekati daerah konsumen atau daerah perkotaan yang relatif padat penduduk dibandingkan daerah tanah kering yang sebagian besar terdapat di wilayah perbukitan dan pegunungan.

Berdasarkan Laporan Badan Pusat Statistik Provinsi Banten tahun 2015 hingga 2019, penggunaan lahan di
Kabupaten Serang didominasi oleh lahan sawah, hortikultura, perkebunan, dan perikanan, yaitu sekitar $70 \%$ dari luas wilayah keseluruhan Kabupaten Serang. Penggunaan lahan sawah di Kabupaten Serang pada tahun 2015 memiliki luas sebesar 48.925 hektar $(33,34 \%)$ dan 47.573 ha $(32,42 \%)$ pada tahun 2019. Sebaran sawah tersebut berada di seluruh kecamatan Kabupaten Serang. Perubahan sebesar 0,92\% terhadap sawah di Kabupaten Serang merupakan tantangan terbesar dalam perwujudan swasembada pangan. Berdasarkan data Badan Pusat Statistik Provinsi Banten 2019, Kabupaten Serang merupakan sentra produksi padi terbesar ketiga di Provinsi Banten, tidak saja mampu memenuhi kebutuhan produksi daerah setempat, tetapi juga menjadi salah satu penyangga pangan di Provinsi Banten. Penggunaan lahan di Kabupaten Serang dari tahun 2015 ke 2019 dapat dilihat pada Gambar 1.

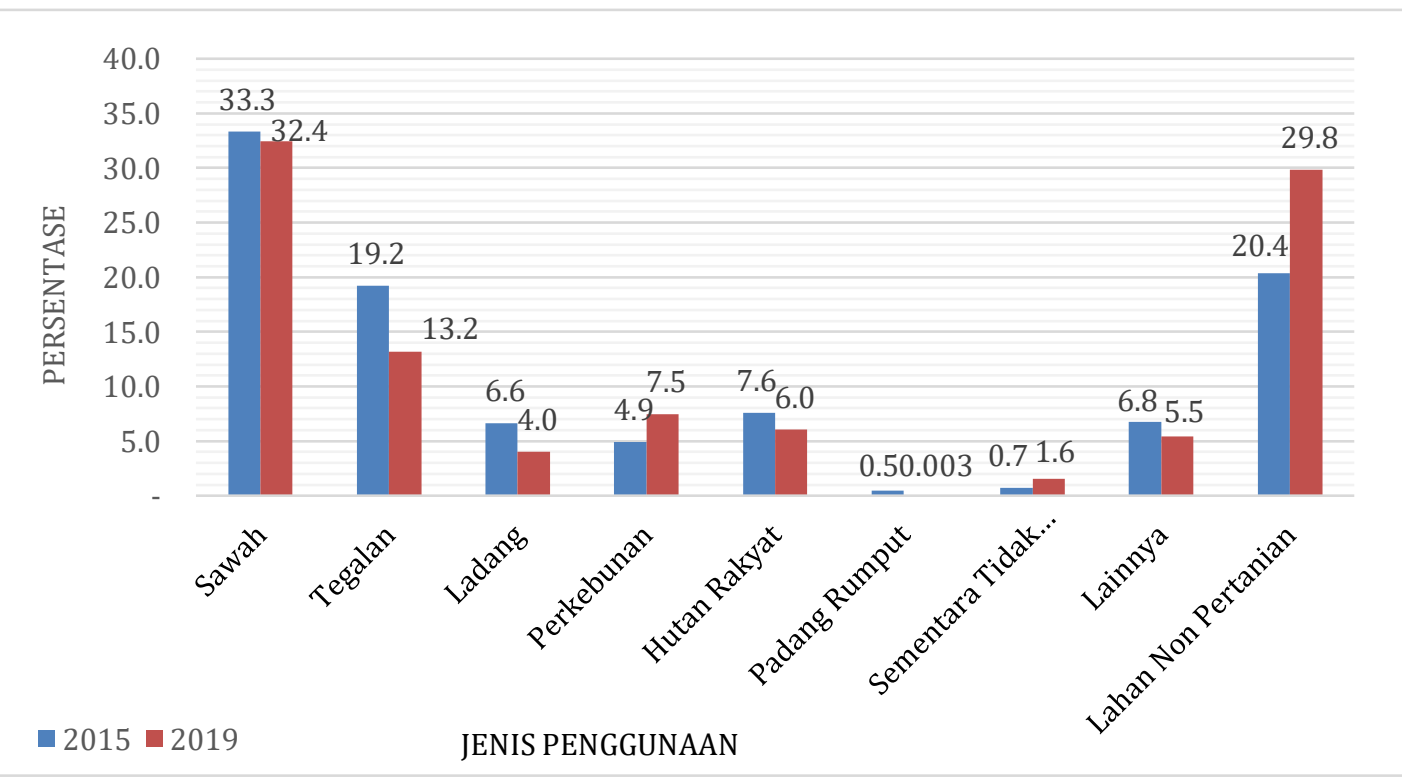

Gambar 1. Penggunaan lahan tahun 2015-2019 di Kabupaten Serang Sumber: Badan Pusat Statistik Kabupaten Serang 2016-2020 (data diolah) 
Laju alih fungsi lahan sawah secara parsial dapat memperlihatkan perubahan penggunaan lahan dari tahun ke tahun dengan mengacu pada tahun sebelumnya. Penggunaan lahan tersebut berubah menjadi lahan non pertanian seperti pemukiman, industri, maupun sarana dan prasarana lainnya. Laju alih fungsi lahan dapat dilihat pada Tabel 1, yang menunjukan adanya penurunan luas lahan sawah di Kabupaten Serang dari tahun 2015 hingga 2019. Penurunan luas sawah yang terjadi pada tahun ketahun bersifat fluktuatif.

Berdasarkan Tabel 1, dapat dilihat bahwa luas lahan sawah di Kabupaten Serang mengalami penurunan sebesar 1.352 ha dalam kurun waktu 2015-2019. Nilai laju penyusutan luas lahan sawah yang diperoleh bertanda negatif, hal ini menggambarkan adanya penyusutan luas lahan sawah akibat adanya alih fungsi lahan. Ini berarti selama 5 tahun luas lahan sawah berkurang sebesar $2,78 \%$ dan rata-rata penyusutan pertahunnya sebesar $0,70 \%$.

Tabel 1. Laju Alih Fungsi Lahan Sawah di Kabupaten Serang Tahun 2015-2019

\begin{tabular}{ccrr}
\hline Tahun & $\begin{array}{c}\text { Luas } \\
\text { Sawah } \\
\text { (Ha) }\end{array}$ & $\begin{array}{c}\text { Luas Sawah } \\
\text { Teralih } \\
\text { fungsi (Ha) }\end{array}$ & $\begin{array}{c}\text { Laju } \\
\text { Penyusuta } \\
\text { n Luas } \\
\text { Lahan (\%) }\end{array}$ \\
\hline 2015 & 48.925 & - & - \\
2016 & 48.011 & 914 & $-1,868$ \\
2017 & 48.001 & 10 & $-0,021$ \\
2018 & 47.574 & 427 & $-0,889$ \\
2019 & 47.573 & 1 & $-0,003$ \\
\hline Jumlah & $\mathbf{1 . 3 5 2}$ & $-\mathbf{2 , 7 8}$ \\
\hline $\begin{array}{c}\text { Rata- } \\
\text { rata }\end{array}$ & $\mathbf{3 3 8}$ & $\mathbf{- 0 , 7 0}$ \\
\hline
\end{tabular}

Sumber: Hasil Olahan Data Penelitian, 2020

Berdasarkan data Badan Pusat Statistik Kabupaten Serang, pada tahun
2015 hingga 2019, jumlah industry di Kabupaten Serang mengalami peningatkan yang signifikan. Hal tersebut akan mengakibatkan peningkatan pada kebutuhan akan lahan, jika lahan kritis sudah dipergunakan semuanya maka bukan tidak mungkin lahan pertanian, terutama lahan sawah yang akan dimanfaatkan.

Pada tahun 2017, pemerintah Kabupaten Serang bersama Kementerian Pertanian dan TNI-AD melaksanakan pembukaan lahan sawah baru dibeberapa wilayah guna mendukung produksi pangan secara nasional juga peningkatan pendapatan ekonomi petani. Namun hal tersebut tidak dapat menutupi luas lahan sawah yang teralihfungsi. Berdasarkan Tabel 1, dapat dilihat bahwa pada tahun 2017 masih terdapat lahan sawah yang mengalami alihfungsi. Sedangkan pada tahun 2019, luas lahan sawah yang teralihfungsi terlihat sedikit, hal tersebut dikarenakan data pada tahun tersebut belum lengkap.

Sejatinya, banyak warga Kabupaten Serang menggantungkan hidupnya dari sektor pertanian. Menurut Dinas Pertanian Kabupaten Serang (2021), diketahui telah dilakukan sensus pertanian pada tahun 2013, saat itu jumlah rumah tangga usaha pertanian di Kabupaten Serang tercatat sebanyak 127.438 rumah tangga. Namun angka tersebut mengalami penurunan sebanyak 30 persen dibandingkan sensus sebelumnya. Dinas Pertanian Kabupaten Serang juga menyatakan bahwa sensus pertanian selanjutnya akan kembali dilakukan pada tahun 2023. 
Tentu jelas, bila lahan persawahan sebagai tulang punggung penghidupan warga semakin tergerus akan semakin banyak warga yang akan kehilangan mata pencahariannya. Banyak petani yang enggan lagi untuk mau mengolah lahan pertanian, terutama lahan sawah dikarenakan sudah banyak yang tidak lagi dimiliki oleh para petani. Akhirnya banyak petani yang memilih untuk menjadi buruh industri.

Data BPS Provinsi Banten tahun 2015 hingga 2019 menunjukkan bahwa hampir seluruh wilayah Kecamatan di Kabupaten Serang mengalami perubahan luas lahan sawah. Wilayah Kecamatan yang paling besar mengalami alih fungsi lahan sawah adalah Kecamatan Tanara, Ciruas, dan Mancak dengan jumlah penurunan luas lahan sawah berturutturut sebesar 478,10 hektar; 340,70 hektar; dan 334,00 hektar. Selain itu terdapat 3 wilayah Kecamatan yang juga mengalami alih fungsi lahan dalam tingkatan sedang. Sedangkan sisanya mengalami alih fungsi lahan sawah pada tingkatan rendah, yaitu sebesar 160,63 hektar hingga tidak mengalami alih fungsi lahan sawah.

Penurunan luas penggunaan lahan sawah yang terjadi di setiap Kecamatan di Kabupaten Serang berkisar antara 0 hektar hingga 478,10 hektar. Rentang nilai penurunan luas lahan sawah dijadikan dasar sebaran tingkat alih fungsi lahan setiap wilayah Kecamatan di Kabupaten Serang. Nilai tersebut kemudian dibagi menjadi tiga kelas tingkatan dengan rentang yang sama, yaitu tinggi, sedang, dan rendah. Secara spasial, sebaran tingkat alih fungsi lahan sawah di Kabupaten Serang tahun 20152019 dapat dilihat pada Gambar 2.

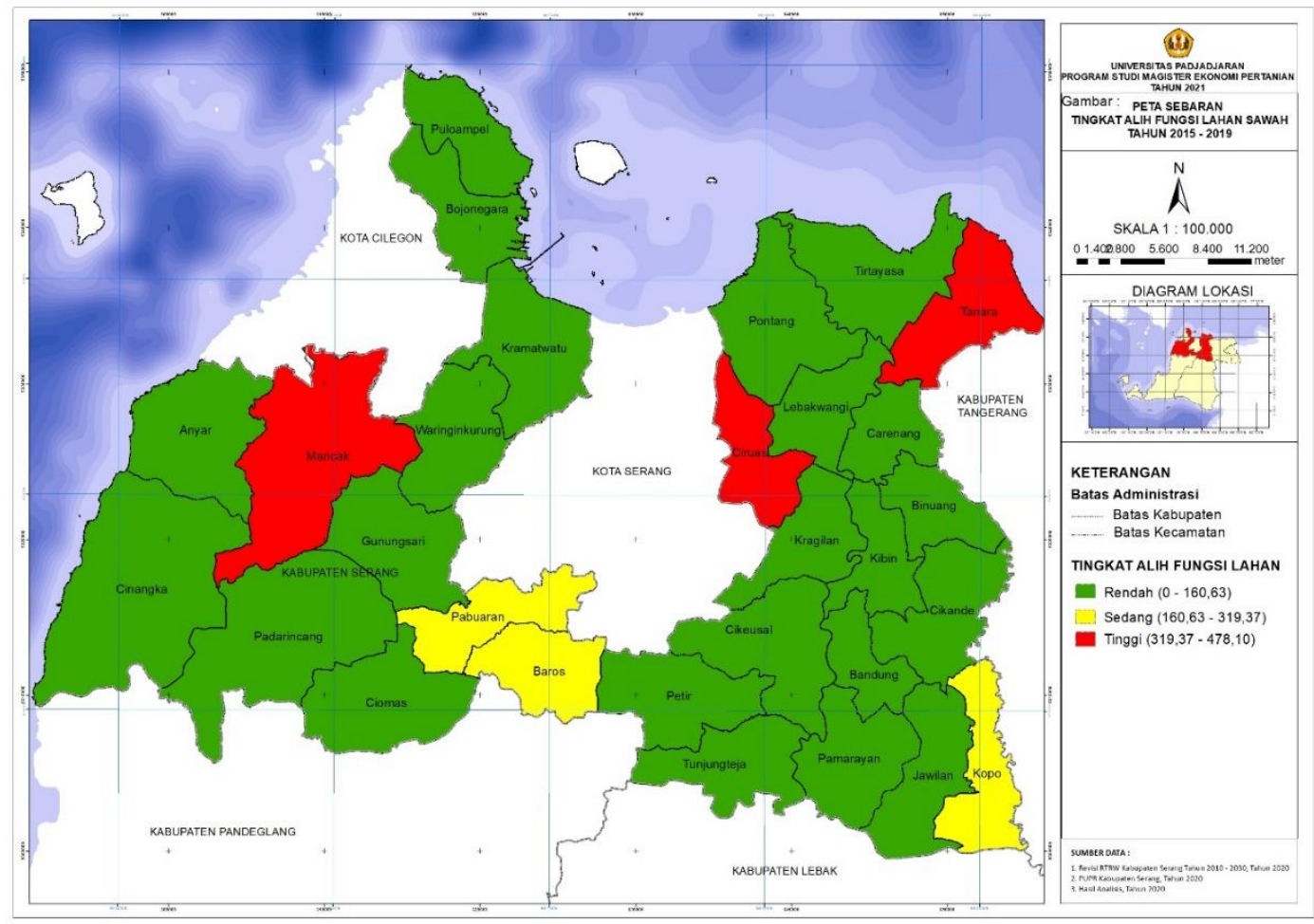

Gambar 2. Peta Sebaran Tingkat Alih Fungsi Lahan Kabupaten Serang Tahun 2015-2019 Sumber: Hasil Olahan Data Penelitian, 2020 
Penggunaan lahan di Kabupaten Serang dari tahun 2015-2019 menunjukkan bahwa perubahan hampir terjadi di seluruh wilayah Kabupaten, bahkan beberapa wilayah kecamatan memperlihatkan perubahan yang cukup besar. Perubahan penggunaan lahan di Kabupaten Serang terjadi secara masif dan secara tidak langsung. Terlihat wilayah Kabupaten Serang Barat, wilayah Serang Tengah yang berbatasan dengan Kota Cilegon, serta wilayahwilayah yang berbatasan dengan Kabupaten Tangerang menunjukan adanya perubahan yang cukup besar.

Kecamatan Tanara merupakan daerah dengan tingkat alih fungsi lahan sawah yang tinggi. Sebagai salah satu daerah dengan sawah paling banyak $(50,87 \%)$, Kecamatan Tanara menjadi salah satu sentra produksi padi di Kabupaten Serang dengan produktivitas mencapai 5,9 ton per hektar. Berdasarkan RTRW Kabupaten Serang Tahun 2011-2031, Kecamatan Tanara menjadi salah satu sentra Kawasan Pengembangan Serang Utara dengan salah satu arahan pengembangannya adalah pariwisata dan pemukiman. Sebagai pengembangan pariwisata pemerintah Kabupaten Serang akan membangun kawasan wisata religi di Kecamatan Tanara. Sehingga sangat dimungkinkan terjadi perubahan penggunaan lahan pertanian di wilayah ini, baik untuk hunian, fasilitas umum, maupun wisata itu sendiri.

Selain itu, wilayah yang berbatasan langsung dengan Kabupaten Tangerang tentunya juga membawa konsekuensi tersendiri pada perkembangan di
Kecamatan Tanara, terutama pemukiman. Menurut Lapatandau et al., (2017), Selain untuk memenuhi kebutuhan industri, alih fungsi lahan juga terjadi secara cepat untuk memenuhi kebutuhan perumahan yang jumlahnya jauh lebih besar.

Selain Kecamatan Tanara di wilayah utara Kabupaten Serang, di wilayah timur pun terjadi alih fungsi lahan sawah yang cukup besar yaitu di Kecamatan Ciruas dengan perubahan penggunaan lahan sawah mencapai 340 hektar. Kecamatan Ciruas merupakan Ibukota Kabupaten Serang dan bagian dari PKLp Ciruas yang memiliki fungsi sebagai pusat pemerintahan kabupaten, pemukiman, sosial, serta perdagangan, dan jasa. Pembangunan di wilayah ini masih berlanjut, selain letaknya yang strategis sebagai jalur penghubung antara Kota Serang dan Kabupaten Tangerang, Kecamatan ini memiliki kepadatan penduduk yang sangat padat.

Suprajaka \& Fitria (2012) mengemukakan bahwa perubahan lahan di Kabupaten Serang dipengaruhi oleh adanya perkembangan Kotamadya Serang sebagai ibukota Provinsi Banten, perkembangan Industri Cilegon dan perkembangan pemukiman kota-kota mandiri di wilayah Kotamadya Tangerang.

Selain berbatasan dengan Kota Serang, sebagain wilayah Kecamatan Ciruas juga berbatasan langsung dengan Kecamatan Pontang dan Lebak Wangi yang memiliki luas lahan sawah terbesar di Kabupaten Serang. Melihat fenomena tentang alih fungsi lahan sawah tidak dapat dihindarkan karena proses 
tuntutan pembangunan serta pertambahan penduduk, tingginya alih fungsi lahan di wilayah Ciruas dikhawatirkan akan merembet ke kawasan pertanian produktif lainnya seperti di Lebak Wangi dan Pontang. Hal ini perlu dikendalikan melalui kebijakan tata ruang yang tegas dan menerbitkan peraturan penentuan luas lahan sawah pangan berkelanjutan serta dikembangkannya sistem dan usaha agribisnis dengan mengakomodir kebutuhan sarana/prasarana disetiap wilayah kecamatan.

Implikasi kebijakan dalam pengendalian alih fungsi lahan sawah sangat penting dilakukan. Baik kebijakan pemerintah pusat maupun kebijakan pemerintah daerah. Alih fungsi lahan sawah merupakan masalah serius yang perlu ditangani oleh pemerintah dengan segera. Sehinggga diperlukan sinergisitas dari segala pihak dalam melaksanakan kebijakan tersebut. Upaya penekanan dan pengendalian alih fungsi lahan sawah dapat dilakukan bersamaan dengan peningkatan produktivitas.

Selain kebijakan-kebijakan dapat pula dilakukan program pembukaan lahan sawah dalam bentuk (1) pemanfaatan lahan terlantar dengan mengembangkan tanaman semusim maupun tahunan, terutama di daerah tarnsmigrasi; (2) pengendalian alih fungsi lahan sawah dengan mempertahankan lahan irigasi yang dalam pencetakan dan pembangunannya telah menghabiskan investasi besar; (3) Perluasan areal sawah dan lahan kering terutama di wilayah selatan Kabupaten Serang yang berbatasan langsung dengan
Kabupaten Pandeglang dan Kabupaten Lebak.

Dinas Pertanian Kabupaten Serang menyatakan bahwa perlindungan lahan pertanian berkelanjutan perlu dilaksanakan untuk mengendalikan alih fungsi lahan, menjaga ketahanan pangan dan kelestarian lingkungan. Dalam implementasinya perlu adanya peraturan yang jelas dan tegas mengatur tentang lahan pertanian yang dilindungi, khususnya lahan sawah, serta sanksi jika terjadi alihfungsi pada lahan yang dilindungi serta insentif yang akan diterima masyarakat jika melindungi lahan tersebut.

\section{SIMPULAN}

Perubahan penggunaan lahan sawah di Kabupaten Serang terjadi hampir pada seluruh kecamatan di Kabupaten Serang. Beberapa wilayah kecamatan memperlihatkan perubahan yang cukup besar, serta terjadi secara masif dan tidak langsung. Peta analisis menunjukan bahwa wilayah berbatasan langsung dengan kota-kota besar seperti Kota Cilegon, Kota Serang, serta Kabupaten Tangerang menunjukan adanya perubahan yang cukup besar. Terdapat tiga kecamatan yang mengalami alih fungsi lahan dalam kategori tinggi, yaitu Kecamatan Tanara, Kecamatan Ciruas dan Kecamatan Mancak. Sedangkan kecamatan yang mengalami alih fungsi lahan dalam kategori sedang yaitu Kecamatan Kopo, Kecamatan Pabuaran, dan Kecamatan Baros.

\section{DAFTAR PUSTAKA}

Azwar, S. (2000). Metode Penelitian. 
Pustaka Pelajar.

Badan Perencanaan Pembangunan Daerah Kabupaten Serang. (2018). Laporan Akhir Penyusunan Rencana Aksi Daerah Pertanian Kabupaten Serang Tahun 2018-2021 (Vol. 1). Pemerintah Kabupaten Serang.

Badan Pusat Statistik Kabupaten Serang. (2013). Angka Sementara Hasil Sensus Pertanian 2013 Kabupaten Serang. Badan Pusat Statistik.

Badan Pusat Statistik Provinsi Banten. (2015). Luas Lahan Menurut Penggunaanya Provinsi Banten 2015. Badan Pusat Statistik.

Badan Pusat Statistik Provinsi Banten. (2019). Luas Lahan Menurut Penggunaanya Provinsi Banten 2019. Badan Pusat Statistik.

Bringezu, S., Schütz, H., Pengue, W., O'Brien, M., F, F. ., Sims, R., \& Herrick, J. (2014). Assessing Global Land Use: Balancing Consumption with Sustainable Supply. A Report of the Working Group on Land and Soils of the International Resource Panel (International Resource Panel Working (ed.)). United Nations Environment Programme.

Hakim, A. (2002). Ekonomi Pembangunan Edisi Pertama. Yogyakarta: EKONISIA.

Hauser, P. M., Gardner, R. W., Laquian, A. A., \& El-Shakhs, S. (1985). Penduduk dan Masa Depan Perkotaan. Yayasan Obor Indonesia.

Irawan, B. (2016). Konversi Lahan Sawah: Potensi Dampak, Pola Pemanfaatannya, dan Faktor Determinan. Forum Penelitian Agro Ekonomi, 23(1), 1. https://doi.org/10.21082/fae.v23n 1.2005.1-18

Lapatandau, Y. A., Rumagit, G. A. J., \& Pakasi, C. B. D. (2017). Alih Fungsi Lahan Pertanian Di Kabupaten Minahasa Utara. Agri-Sosioekonomi,

13(2A), 1. https://doi.org/10.35791/agrsosek. 13.2a.2017.16548

Mubyarto. (1996). Pengantar Ekonomi Pertanian. Edisi Ketiga. Jakarta: LP3ES.

Muiz, A., Murtilaksono, K., \& Saleh, M. B. (2009). Analisis Perubahan Penggunaan Lahan di Kabupaten Sukabumi [Institut Pertanian Bogor]. http://repository.ipb.ac.id/handle/1 23456789/41218

Munibah, K., Sitorus, S. R. P., Rustiadi, E., Gandasasmita, K., \& Hartrisari, H. (2009). Model Hubungan Antara Jumlah Penduduk Dengan Luas Lahan Pertanian Dan Permukiman (Studi Kasus DAS Cidanau, Provinsi Banten). Jurnal Ilmu Tanah Dan Lingkungan, 11(1), 32-40. https://doi.org/10.29244/jitl.11.1.3 $2-40$

Mustopa, Z. (2011). Analisis FaktorFaktor yan Mempengaruhi Alih Fungsi Lahan Pertanian di Kabupaten Lebak. Semarang: Universitas Diponogoro.

Ruswandi, A., Rustiadi, E., \& Mudikdjo, K. (2007). Dampak Konversi Lahan Pertanian Terhadap Kesejahteraan Petani Dan Perkembangan Wilayah : Studi Kasus Di Daerah Bandung Utara Impact of Agricultural Land Conversion Toward Farmer ' S Welfare and Regional Development: Case. Agro Ekonomi, 25(2), 207-219.

Steinhäußer, R., Siebert, R., Steinführer, A., \& Hellmich, M. (2015). National and regional land-use conflicts in Germany from the perspective of stakeholders. Land Use Policy, 49(2015), 183-194. https://doi.org/10.1016/j.landusep ol.2015.08.009

Suprajaka, \& Fitria, M. D. (2012). Analisis Dinamika Pemanfaatan Lahan Pertanian Di Kota Dan Kabupaten 
JURNAL AGRICA Vol.14 No.2/Oktober 2021

Available online http://ojs.uma.ac.id/index.php/agrica 10.31289/agrica.v14i2.5039

Serang (Studi Kasus: Kecamatan Kramatwatu, Kasemen, Dan Pontang). Jurnal Planesia, 3(1).

Widiatmaka, P. B. ., Wiwin, A., Munibah Khursatul, \& Santoso. (2013). Analisis Perubahan Penggunaan
ISSN 1979-8164 (Print) ISSN 2541-593X (Online)

Lahan dan Kesesuaian Lahan Untuk Sawah Di Sepanjang Jalur Jalan Tol Jakarta-Cikampek Dan Jalan Nasional Pantura, Kab. Karawang. Forum Ilmiah Tahunan Ikatan Surveyor Indonesia, 3, 7-14. 